\title{
Prosument jako aktywny uczestnik działań marketingowych*
}

\section{Wstęp}

W klasycznym podejściu do sposobu funkcjonowania rynku dóbr konsumpcyjnych występował wyraźny podział na sferę konsumpcji i sferę wytwórczą [Humphreys and Grayson 2008] $]^{1}$. Jego konsekwencją było jednoznaczne rozgraniczenie ról rynkowych spełnianych przez głównych uczestników tego rynku, jakimi byli nabywcy finalni i konsumenci oraz producenci. Do każdej z tych ról był przypisany określony zakres aktywności rynkowej. W przypadku nabywców finalnych obejmował on przede wszystkim dokonywanie zakupu dostępnych na rynku produktów, w przypadku konsumentów natomiast obejmował on użytkowanie nabytych wyrobów i usług. Obie wymienione grupy reprezentowały sferę konsumpcji jako odbiorcy oferty wytwarzanej i udostępnianej na rynku przez producentów. Ich aktywność polegała z kolei na wytwarzaniu produktów. Spełniali tym samym funkcję ich dostawców.

Dynamiczne zmiany zachodzące w ostatnich latach, zwłaszcza o charakterze społecznym, kulturowym i technologicznym, doprowadziły do całkowitej rekonfiguracji ról rynkowych odgrywanych przez odbiorców i dostawców produktów konsumpcyjnych. Jej odzwierciedleniem stał się zdecydowany wzrost

\footnotetext{
*Artykuł został przygotowany w ramach projektu badawczego 2013/11/B/HS4/00430 finansowanego przez NCN.

${ }^{1}$ Dążenie nabywców do zaspokajania potrzeb niematerialnych, zwłaszcza związanych z realizacją swoich pasji, dostrzega również Dougherty [2012]. Można wręcz powiedzieć, że poszukując form ich spełnienia, odkrywają możliwość współkreowania wartości marketingowych, poprzez traktowanie je jako swego rodzaju wyzwanie pozwalające na zerwanie z szablonowym podejściem do codzienności.
} 


\section{4}

aktywności odbiorców, przede wszystkim zaś zmiana jej zakresu przedmiotowego. Poszukując nowych sposobów zaspokajania rosnących oczekiwań, zwłaszcza o charakterze niematerialnym, dostrzegli oni, że można je spełniać poprzez angażowanie się w działania przypisywane wcześniej wyłącznie oferentom [Humphreys i Grayson 2008]. Jako coraz bardziej świadomi uczestnicy rynku zaczęli oni zatem wykazywać gotowość do uczestniczenia w działaniach marketingowych związanych z kształtowaniem oferty, począwszy od etapu jej przygotowania, czyli planowania, kończąc na kreowaniu wartości marketingowych stanowiących zwieńczenie gotowej oferty w postaci chociażby jej wizerunku. Dążenie do aktywnego włączania się w te działania spowodowało przejęcie znacznej części form aktywności od oferentów, które dotychczasowi odbiorcy zaczęli realizować wspólnie $\mathrm{z}$ nimi. Było to równoznaczne $\mathrm{z}$ wyłonieniem się nowej roli rynkowej, jaką jest rola prosumenta ${ }^{2}$, czyli aktywnego nabywcy lub aktywnego konsumenta ${ }^{3}$.

W literaturze przedmiotu można zauważyć także różne inne określenia, które przez ich autorów są traktowane jako synonim prosumenta. Należą do nich m.in. współtwórca wartości [Prahalad i Ramaswamy 2004], zaangażowany konsument, innowacyjny konsument, produkujący konsument, pracujący konsument itp. [Rieder i Voß 2010]. Wydaje się jednak, że prosument jako podmiot wpisujący się w zjawisko prosumpcji stanowi określenie najlepiej odzwierciedlające specyfikę roli rynkowej odgrywanej współcześnie przez coraz większą część nabywców. Pozostałe z wymienionych przykładowo określeń opisują natomiast raczej cechy charakteryzujące współczesnego aktywnego nabywce jako osobę współuczestniczącą w kreowaniu wartości marketingowych, co wymaga ich dużego zaangażowania, którego efektem niejednokrotnie jest innowacyjne rozwiązanie. Z kolei określenie produkujący konsument ma raczej obrazować fakt przejęcia przez konsumentów od producentów części przypisywanej im wcześniej aktywności. Należy je zatem traktować jako pewien symbol, gdyż prosument nie jest w stanie faktycznie zastąić wytwórców w procesie produkcyjnym z powodów braku odpowiedniego wyposażenia technicznego i technologicznego.

Wyjątkiem są jedynie produkty o charakterze niematerialnym, zwłaszcza kreowane w środowisku wirtualnym, w przypadku których rzeczywiście ich dotychczasowi odbiorcy mogą stać się niejednokrotnie w pełni ich wytwórcami. Wynika to ze specyfiki tej grupy produktów. Być może właśnie dlatego część

\footnotetext{
${ }^{2}$ Rolę tą można uznać za nowe hybrydowe połączenie form aktywności przypisywanych wcześniej wyłącznie nabywcom z formami aktywności przypisywanych tylko oferentom (por. Bruns 2009), http://produsage.org/node/67 [dostęp: 04.02.2017].

${ }^{3}$ Zdecydowanie wyższy poziom aktywności jako cechę prosumentów odróżniającą ich od nabywców podkreśla także m.in. Kimmel [2015]. Niesłusznie jednak aktywność prosumpcyjną odnosi wyłącznie do kreowania produktów.
} 
autorów utożsamia prosumpcję wyłącznie $\mathrm{z}$ aktywnością internetową ${ }^{4} \mathrm{~W}$ odniesieniu do aktywności $\mathrm{w}$ tym środowisku używa się z kolei określenia $\mathrm{z}$ ang. produser [Bruns 2008], co wynika zapewne z niematerialnego charakteru oferty wirtualnej. Ograniczanie prosumpcji do aktywności w Internecie jest jednak nieuzasadnionym zawężaniem zasięgu tego zjawiska. Aktywność prosumpcyjną można bowiem przejawiać także poza siecią wirtualną, współtworząc z oferentami lub innymi nabywcami różnorodne wartości, począwszy od produktów i ich atrybutów marketingowych (opakowań, marek itd.), kończąc na reputacji czy wizerunku.

Jak widać, można spełniać funcję prosumenta zarówno w Internecie, jak i w świecie realnym. Można nim być ponadto zarówno w ramach relacji z oferentami (producentami, usługodawcami i handlowcami), jak i w relacjach $z$ innymi nabywcami ${ }^{5}$. Zawsze jednak niezależnie, czy określone wartości są współkreowane z oferentami ${ }^{6}$, czy z nabywcami, efekty aktywności prosumenta odczuwa oferent, np. w postaci określonego sposobu jego postrzegania bazującego na aktywności komunikacyjnej odbywającej się między nabywcami. Warto podkreślić, że konfiguracja ról rynkowych wynikająca z pojawienia się prosumpcji odzwierciedla nie tylko zdecydowany wzrost aktywności nabywców. Wymaga ona jednoczesnego zdecydowanego zwiększenia poziomu aktywności oferentów, którzy muszą stworzyć warunki sprzyjające partycypacji prosumentów $\mathrm{w}$ procesie kreacji marketingowej, poprzez umiejętne wykorzystywanie ich spontanicznej aktywności oraz równoległe tworzenie systemu bodźców wzbudzających ich gotowość do zaangażowania w działania marketingowe.

Współczesnych odbiorców ${ }^{7}$ można podzielić na trzy podstawowe grupy:

1. Nabywców, czyli osoby, których aktywność rynkowa polega na dokonywaniu zakupu produktów, które nie wykazują gotowości do angażowania się w działania marketingowe.

\footnotetext{
${ }^{4}$ Podejście takie jest zaprezentowane m.in. przez Frayssé'a [2015].

Można oczywiście wskazać znacznie więcej typów prosumpcji, biorąc pod uwagę inne kryteria. Przykładowo, Mitręga wyróżnia prosumpcję racjonalizatorską i ekshibicjonistyczną (por. Mitręga 2015).

${ }^{5}$ Jak słusznie zauważają Pejas-Matysik, Szafrańska oraz Krasnodębski, prosumpcja jest zjawiskiem niezwykle złożonym, które ponadto podlega dynamicznym zmianom.

${ }^{6} \mathrm{~W}$ zależności od stopnia zaangażowania w działania przedsiębiorstwa Szul wyodrębnia trzy typy prosumentów. Jeden z nich określa mianem innowacyjnych prosumentów (por. Szul 2015). Jest to równoznaczne $z$ dostrzeganiem faktu, że aktywność prosumentów nie zawsze ma charakter innowacyjny, mimo iż część autorów niesłusznie przypisuje tą cechę wszystkim działaniom prosumentów.

${ }^{7}$ Określenie to zostało użyte w odniesieniu do reprezentantów klasycznie rozumianej strony popytowej. Obejmuje ono zarówno biernych, jak i aktywnych nabywców.
} 
2. Potencjalnych prosumentów, czyli osoby, których aktywność rynkowa polega na dokonywaniu zakupu produktów, które wykazują ponadto gotowość do angażowania się $\mathrm{w}$ działania marketingowe.

3. Faktycznych prosumentów, czyli osoby, których aktywność rynkowa polega na dokonywaniu zakupów i angażowaniu się w sposób spontaniczny lub pod wpływem inspirowania przez oferentów w działania marketingowe.

Oczywiście w przypadku każdej z wymienionych grup oferenci powinni przejawiać dużą aktywność, począwszy od wzbudzania otwartej postawy wobec prosumpcji u klasycznych nabywców, poprzez jej umacnianie i zamianę na zachowanie rynkowe w przypadku potencjalnych prosumentów, kończąc na utrwalaniu i rozwijaniu zachowań prosumpcyjnych w przypadku faktycznych prosumentów. Należy podkreślić, że wzrost aktywności oferentów, podobnie, jak w przypadku nabywców, pociaga za sobą wyraźne zmiany roli rynkowej, jaką oni spełniają. Włączając prosumentów w działania marketingowe i/lub korzystając $\mathrm{z}$ ich spontanicznej aktywności, stają się jednocześnie odbiorcami ${ }^{8}$ pomysłów prosumentów stworzonych dzięki ich wiedzy, doświadczeniom, umiejętnościom itp. Widoczne w klasycznej konfiguracji ról rynkowych wyraźne rozgraniczenie roli odbiorcy i dostawcy współcześnie ustępuje zatem miejsca ich przenikaniu się. Jedna i druga strona staje się tym samym dostawcą i odbiorcą określonych wartości materialnych i/lub niematerialnych. $Z$ tym aspektem prosumpcji należy zatem raczej utożsamiać przejmowanie przez prosumentów kompetencji przypisywanych wcześniej oferentom, nie zaś z dosłownie rozumianym przejęciem od nich czynności wytwórczych.

Należy ponadto dodać, że chociaż określenie prosument (jako połączenie elementu pojęcia producent i elementu pojęcia konsument) odnosi się tylko do współdziałania $\mathrm{z}$ wytwórcami ${ }^{9}$, w ramach prosumpcji dochodzi do współpracy aktywnych nabywców z różnymi oferentami, w tym także $\mathrm{z}$ handlowcami, z którymi wspólnie można tworzyć pozaproduktowe elementy oferty marketingowej. Ponadto, niezależnie od tego, czy prosumenci współpracują z oferentami, czy też z innymi nabywcami, zawsze korzyści z takiego współdziałania odnoszą

\footnotetext{
${ }^{8}$ Niektórzy autorzy w odniesieniu do producentów używają wręcz określenia konsumujący wytwórcy (por. Bauer i Gegenhuber, 2015), które wraz z określeniem produkujący konsumenci ma odzwierciedlać przenikanie się roli dostawcy i odbiorcy.

${ }^{9}$ Toffler jako twórca pojęcia prosumpcji odnosił je do przenikania się sfery wytwórczej i sfery konsumpcji, co znajduje odzwierciedlenie także w sformułowaniu prosument [Toffler, 1980]. Dostrzegał on jednak ewolucję zachodzącą w przypadku tego zjawiska (por. Toffler 1990). Jednym z elementów tej ewolucji, zdaniem autorki, jest właśnie konieczność rozszerzenia zasięgu podmiotowego prosumpcji na inne grupy oferentów, w tym na handlowców.
} 
obie strony ${ }^{10}$, co dodatkowo stymuluje ich dalszą współpracę, prowadząc wręcz do partnerstwa marketingowego. Tym bardziej zatem należy analizować różne aspekty postaw i zachowań prosumentów ${ }^{11}$.

Biorąc pod uwagę przedstawione rozważania, w niniejszym artykule dążono do osiągnięcia następujących celów badawczych:

1. Zidentyfikowania gotowości respondentów do angażowania się w działania marketingowe.

2. Określenia zróżnicowania zakresu zachowań prosumpcyjnych respondentów ze względu na ich gotowość do angażowania się w działania marketingowe lub jej brak.

3. Opracowania profili semantycznych dla respondentów jako potencjalnych lub faktycznych prosumentów.

$\mathrm{W}$ procesie realizacji celów badawczych weryfikacji empirycznej poddano następującą hipotezę badawczą: postawa respondentów wobec aktywności marketingowej jest cechą różnicującą zakres ich zachowań prosumpcyjnych.

\section{Charakterystyka badań empirycznych}

Dążąc do osiagnięcia celów badawczych oraz do zweryfikowania sformułowanej hipotezy, przeprowadzono badania pierwotne. Zostały one zrealizowane w ramach projektu badawczego 2013/11/B/HS4/00430 finansowanego przez NCN. Badania właściwe przeprowadzono w trzecim kwartale 2015 roku wśród 1200 osób reprezentujących polskich pełnoletnich nabywców finalnych. Do analizy statystycznej zakwalifikowano 1012 poprawnie wypełnionych kwestionariuszy ankiety. W badanej populacji 61\% stanowily kobiety. Zastosowano nielosowy dobór próby badawczej. Badania miały charakter bezpośredni wymagający osobistego kontaktu ankietera z respondentami. Umożliwiło to uzyskanie bardzo dużej wartości wskaźnika zwrotów kompletnie wypełnionych kwestionariuszy.

Zakres przedmiotowy badań obejmował m.in. 15 zachowań związanych $\mathrm{z}$ aktywnością prosumpcyjną, które zostały wyłonione na podstawie analizy poznawczo-krytycznej literatury przedmiotu oraz na podstawie wyników badań

\footnotetext{
${ }^{10}$ Warto jednak dodać, że mogą im towarzyszyć pewne aspekty negatywne (por. Cova, Dalli i Zwick 2011), zwłaszcza w przypadku nieetycznego postępowania którejś ze stron. Wystapienie takiej sytuacji podważa jednak istotę partnerskiego współdziałania, którego podstawą zawsze jest obustronne zaufanie. Jego wzbudzenie i utrzymanie nie jest możliwe bez przestrzeganie zasad etyki, którą uznaje się współcześnie wręcz za nadrzędną wartość społeczną i gospodarczą (por Arvidsson 2010).

${ }^{11}$ Mimo ewidentnych pozytywnych efektów aktywności prosumpcyjnej, należy się zgodzić z opinią Ritzera, iż zjawisko to pozostaje niszowym przedmiotem badań (por. Ritzer 2014).
} 
pilotażowych. Każde $\mathrm{z}$ tych zachowań respondenci mieli ocenić w pięciostopniowej skali Likerta, w której 5 oznaczało zdecydowanie tak; 4 - raczej tak; 3 - ani tak, ani nie; 2 - raczej nie; 1 - zdecydowanie nie.

Dane pierwotne zebrane podczas badań właściwych zostały wykorzystane w dalszych etapach procesu badawczego polegających na przeprowadzeniu analizy statystycznej za pomocą testu niezależności Kruskala-Wallisa oraz analizy profili semantycznych.

Test Kruskala-Wallisa (KW) jako nieparametryczny odpowiednik jednoczynnikowej analizy wariancji jest stosowany, gdy dane nie spełniają wymagań dla przeprowadzenia podobnych testów parametrycznych, ale można je uporządkować według określonych kryteriów (tzn. są mierzone na skali porządkowej). Polega on na sprawdzeniu, czy liczba niezależnych wyników z grupy pochodzi z tej samej populacji, czy z populacji z taką samą medianą. Poszczególne próbki nie muszą mieć takiej samej liczebności. Danymi wejściowymi jest $n$-elementowa próba statystyczna podzielona na $k$ rozłącznych grup ankietowanych o licznościach od $n_{1}$ do $n_{\mathrm{k}}$.

Interpretacji testu Kruskala-Wallisa dokonuje się, oceniając wartość poziomu istotności, która nie powinna przekraczać założonej wartości równej 0,05. Bierze się ponadto pod uwagę wartość tego testu, aby ocenić zróżnicowanie pomiędzy grupami. Duże wartości statystyki testu świadczą o dużym zróżnicowaniu w poszczególnych grupach, przy czym im te wartości są większe, tym zróżnicowanie jest większe. Zróżnicowanie z kolei jest różnicą pomiędzy grupą reprezentowana przez wartość mediany największej do najmniejszej [Mynarski 2003]. Test Kruskala-Wallisa, czyli nieparametryczny odpowiednik ANOVA, pozwala zatem na znalezienie odpowiedzi na pytanie, czy zróżnicowanie pod kątem wydzielenia poszczególnych grup jest na tyle statystycznie istotne, aby móc powiedzieć, że zdanie respondentów określone analizowaną odpowiedzią jest znacząco różne.

Z punktu widzenia kryteriów statystycznych w przypadku testu KW dane nie muszą spełniać wielu wymagań. Jedynymi wymogami do jego przeprowadzenia są [Mynarski 2003]:

- zmienna zależna powinna być mierzona na skali co najmniej porządkowej (może być również mierzona na skali ilościowej),

- obserwacje w analizowanych grupach powinny być niezależne wobec siebie, co oznacza, że osoba będąca w jednej grupie nie powinna być również $\mathrm{w}$ innej porównywanej grupie; wymóg ten spełniają pytania dychotomiczne pozwalające na dokonanie podziału respondentów na rozłączne grupy (np. podział respondentów na kobiety i mężczyzn) oraz pytania jednokrotnego wyboru.

Analizy statystycznej danych pierwotnych zebranych podczas badań ankietowych dokonano przy użyciu pakietu Statistica 8.0. 


\section{Wyniki badań}

Prawie $41 \%$ respondentów (tab. 1) wyrażało chęć uczestniczenia w działaniach marketingowych. Można ich zatem uznać za potencjalnych prosumentów, czyli osoby wykazujące świadomą gotowość do zaangażowania się w aktywność prosumpcyjną jako współkreatorzy szeroko rozumianej oferty marketingowej. Warto dodać, że znacznie większa część badanych była zdania, iż nabywcy powinni uczestniczyć w przygotowywaniu oferty marketingowej. Widać zatem, że w odniesieniu do siebie ankietowani wykazywali relatywnie większą ostrożność, uznając jednak, iż inni nabywcy powinni brać udział w działaniach marketingowych.

Tabela 1

Opinie respondentów na temat uczestniczenia w działaniach marketingowych [\%]

\begin{tabular}{|l|c|c|}
\hline \multirow{2}{*}{ Oceniane przez respondentów stwierdzenia } & \multicolumn{2}{|c|}{ Wskazania [\%] } \\
\cline { 2 - 3 } & tak & nie \\
\hline $\begin{array}{l}\text { Chciałbym(łabym) angażować się w przygotowywanie produktów, } \\
\text { reklam i innych elementów oferty }\end{array}$ & 40,8 & 59,2 \\
\hline $\begin{array}{l}\text { Nabywcy powinni brać udział w przygotowywaniu oferty } \\
\text { wraz z oferentami }\end{array}$ & 64,7 & 35,3 \\
\hline
\end{tabular}

Źródło: Opracowanie własne na podstawie wyników przeprowadzonych badań.

Jak wynika z przeprowadzonych badań, ponad połowa badanych nie przejawiała otwartej postawy w odniesieniu do takiej aktywności, ale wydaje się, że odsetek osób gotowych ją podjąć był jednak duży. Nasuwa się pytanie, czy specyfika postaw ankietowanych $\mathrm{w}$ tym zakresie miała znaczenie, jeśli chodzi o ich rzeczywiste zachowania rynkowe?

W celu określenia zróżnicowania między respondentami wykazującymi gotowość do udziału w działaniach marketingowych i ankietowanymi, którzy nie deklarowali chęci takiego zaangażowania zastosowano test Kruskala-Wallisa (KW). Jak wynika z tabeli 2, statystycznie istotne okazały się różnice między aktywnością prosumpcyjną w przypadku prawie wszystkich, czyli 14 z 15 analizowanych zachowań. Wartość wyznaczonego poziomu istotności (p) była bowiem dla nich mniejsza od przyjętej wartości krytycznej równej 0,05 . Największe różnice występowały w odniesieniu do formy oznaczonej symbolem D1 (wartość testu $\mathrm{KW}=65,0296$ ), D3 (wartość testu KW = 63,4407) oraz D4 (wartość testu $\mathrm{KW}=50,2811$ ). Wyniki testu $\mathrm{KW}$ wskazują tym samym, że analizowana cecha rzeczywiście różnicowała aktywność respondentów. Hipotezę badawczą mówiącą, że postawa respondentów wobec aktywności marketingowej jest cechą różnicującą zakres ich zachowań prosumpcyjnych można zatem potwierdzić. Warto 


\section{Tabela 2}

Analiza istotności różnic za pomocą testu Kruskala-Wallisa między odpowiedziami badanych ze względu na deklarowaną gotowość do uczestniczenia w działaniach marketingowych lub jej brak

\begin{tabular}{|c|c|c|c|}
\hline Analizowana forma aktywności prosumpcyjnej & Symbol & $\begin{array}{l}\text { Wartość } \\
\text { testu KW }\end{array}$ & \begin{tabular}{|c|} 
Poziom \\
istotności $(p)$
\end{tabular} \\
\hline 1 & 2 & 3 & 4 \\
\hline $\begin{array}{l}\text { Wyrażam swoje opinie i uwagi na temat produktów, } \\
\text { z których korzystam za pomocą Internetu (np. na } \\
\text { forum internetowym, na stronie sklepu), ale nie kon- } \\
\text { taktuję się bezpośrednio z ich producentem }\end{array}$ & D1 & 65,0296 & 0,0000 \\
\hline $\begin{array}{l}\text { Wyrażam swoje opinie i uwagi na temat produktów, } \\
\text { z których korzystam bez użycia Internetu (znajomym/ } \\
\text { /rodzinie czy bezpośrednio w sklepie itp.), ale nie } \\
\text { kontaktuję się bezpośrednio z ich producentem }\end{array}$ & D2 & 11,9231 & 0,0006 \\
\hline $\begin{array}{l}\text { Dodaję komentarze do istniejących w Internecie opinii } \\
\text { innych konsumentów na temat produktów, z których } \\
\text { korzystam }\end{array}$ & D3 & 63,4407 & 0,0000 \\
\hline $\begin{array}{l}\text { Zapoznaję się z opiniami innych konsumentów za- } \\
\text { mieszczonymi w Internecie na temat produktów, } \\
\text { z których korzystam lub zamierzam korzystać }\end{array}$ & D4 & 50,2811 & 0,0000 \\
\hline $\begin{array}{l}\text { Zapoznaje się z opiniami innych konsumentów nie } \\
\text { zamieszczonymi w Internecie na temat produktów, } \\
\text { z których korzystam lub zamierzam korzystać (np. } \\
\text { od znajomych/rodziny, sprzedawcy itp.) }\end{array}$ & D5 & 7,9997 & 0,0047 \\
\hline $\begin{array}{l}\text { Z własnej inicjatywy kontaktuję się z producentami za } \\
\text { pomocą Internetu, wyrażając opinię/dając wskazówki } \\
\text { na temat produktów, z których korzystam lub zamie- } \\
\text { rzam korzystać }\end{array}$ & D6 & 14,7193 & 0,0001 \\
\hline $\begin{array}{l}\text { Z własnej inicjatywy kontaktuję się z producentami } \\
\text { bez użycia Internetu, wyrażając opinię/dając wska- } \\
\text { zówki na temat produktów, z których korzystam lub } \\
\text { zamierzam korzystać }\end{array}$ & D7 & 10,3844 & 0,0013 \\
\hline $\begin{array}{l}\text { Z własnej inicjatywy kontaktuję się w różny sposób } \\
\text { z producentami za pomocą Internetu, zadając pytania } \\
\text { na temat produktów, z których korzystam lub zamie- } \\
\text { rzam korzystać }\end{array}$ & D8 & 18,9948 & 0,00001 \\
\hline $\begin{array}{l}\text { Z własnej inicjatywy kontaktuję się w różny sposób } \\
\text { z producentami bez użycia Internetu, zadając pytania } \\
\text { na temat produktów, z których korzystam lub zamie- } \\
\text { rzam korzystać }\end{array}$ & D9 & 14,5329 & 0,0001 \\
\hline $\begin{array}{l}\text { Uczestnicze w działaniach/akcjach organizowanych } \\
\text { przez firmy przez Internet, dzięki którym jestem } \\
\text { współtwórca produktu lub jego atrybutów, np. opako- } \\
\text { wania, marki itp. }\end{array}$ & D10 & 23,8017 & 0,00000 \\
\hline
\end{tabular}


Tabela 2 cd.

\begin{tabular}{|l|c|c|c|}
\hline \multicolumn{1}{|c|}{1} & 2 & 3 & 4 \\
\hline $\begin{array}{l}\text { Uczestnicze w działaniach/akcjach organizowanych } \\
\text { przez firmy w inny sposób niż przez Internet, dzięki } \\
\text { którym jestem współtwórca produktu lub jego atrybu- } \\
\text { tów, np. opakowania, marki itp. }\end{array}$ & D11 & 23,0124 & 0,00000 \\
\hline $\begin{array}{l}\text { Uczestniczę w działaniach/akcjach organizowanych } \\
\text { przez firmy przez Internet, dzięki którym jestem } \\
\text { współtwórca działań promocyjnych, np. hasła/sloganu } \\
\text { reklamowego, kampanii reklamowej itp. }\end{array}$ & D12 & 22,0086 & 0,00000 \\
\hline $\begin{array}{l}\text { Uczestniczę w działaniach/akcjach organizowanych } \\
\text { przez firmy w inny sposób niż przez Internet, dzięki } \\
\text { którym jestem współtwórca działań promocyjnych, } \\
\text { np. hasła/sloganu reklamowego, kampanii reklamo- } \\
\text { wej itp. }\end{array}$ & D13 & 25,3978 & 0,00000 \\
\hline $\begin{array}{l}\text { Uczestniczę w działaniach/akcjach organizowanych } \\
\text { przez firmy w różny sposób, dzięki którym jestem } \\
\text { współtwórca jakichkolwiek innych działań/elementów } \\
\text { firmy, poza produktem i promocją }\end{array}$ & D14 & 29,3031 & 0,00000 \\
\hline $\begin{array}{l}\text { Samodzielnie wytwarzam, ze względów oszczędno- } \\
\text { ściowych czy praktycznych, produkty, z których ko- } \\
\text { rzystam (nie kontaktując się w ogóle z producentem) }\end{array}$ & D15 & 0,2009 & 0,6540 \\
\hline
\end{tabular}

Źródło: Opracowanie własne na podstawie wyników przeprowadzonych badań własnych.

także dodać, że ankietowani nie wyrażający chęci uczestniczenia w przygotowywaniu ofert znacznie rzadziej deklarowali podejmowanie poszczególnych form aktywności prosumpcyjnej niż osoby pragnące angażować się w ten proces. Wyjątkiem była tylko aktywność polegająca na wytwarzaniu produktów na własne potrzeby (D15). W jej przypadku poziom istotności był bowiem znacznie wyższy od przyjętej wartości granicznej 0,05.

Wyniki testu Kruskala-Wallisa znajdują odzwierciedlenie w profilach semantycznych stworzonych dla obu analizowanych grup respondentów (rys.). Relatywnie większe różnice są widoczne dla zachowań komunikacyjnych o charakterze internabywczym w porównaniu z zachowaniami polegającymi na inspirowanej lub spontanicznej współpracy z oferentami. Należy jednak podkreślić, że w przypadku prawie każdego zachowania aktywniejsze były osoby wykazujące świadomą gotowość do angażowania się w działania marketingowe niż osoby niecechujące się otwartą postawą pod tym względem. Jedynie w odniesieniu do zachowania polegającego na przygotowywaniu produktów na własne potrzeby bez względu na zamkniętą lub otwartą postawę ankietowanych zakres ich faktycznej aktywności był praktycznie taki sam.

Warto także zwrócić uwagę, że w przypadku zachowań internabywczych ankietowani wykazywali znacznie większą aktywność niż w przypadku zachowań 


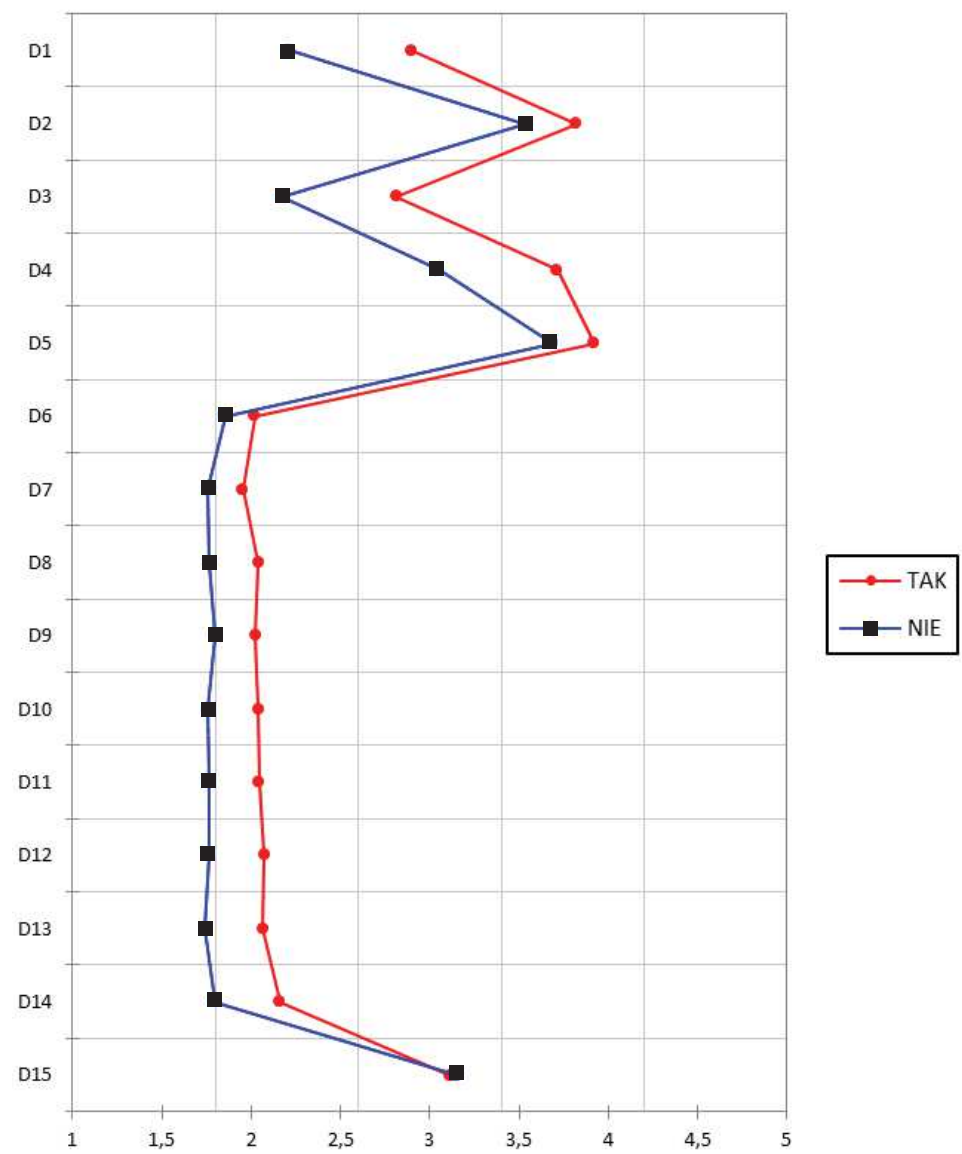

D1 - D15 - analizowane formy aktywności analogicznie jak w tabeli 1; 5 - zdecydowanie tak; 4 - raczej tak; 3 - ani tak, ani nie; 2 - raczej nie; 1 - zdecydowanie nie

\section{Rysunek}

Profile semantyczne odzwierciedlające aktywność prosumpcyjną respondentów zależnie od wykazywania przez nich gotowości do uczestniczenia w działaniach marketingowych lub jej braku

Źródło: Opracowanie własne na podstawie wyników przeprowadzonych badań.

związanych ze współpraca z oferentami. Dotyczyło to obu analizowanych grup respondentów, czyli zarówno osób wykazujących otwartość na udział w procesie kreacji marketingowej, jak i osób nieprzejawiających takiej postawy. W przypadku współpracy z oferentami wartość oceny średniej dla osób gotowych do angażowania się w działania marketingowe była zbliżona do 2,00 lub nieznacznie ją przekraczała, podczas gdy dla zachowań internabywczych była co najmniej bliska 3,00, a w przypadku dwóch zachowań (oznaczonych symbolami D2 i D5) zbliżała się nawet do 4,00. 
Na podstawie wyników przeprowadzonych badań można stwierdzić, że potencjalni prosumenci okazali się także uczestnikami rynku wykazującymi większą aktywność niż osoby, które nie wykazywały porównywalnego potencjału prosumpcyjnego. Było to widoczne zarówno w przypadku zachowań komunikacyjnych podejmowanych wobec innych nabywców, jak i w przypadku zachowań komunikacyjnych i kreatywnych podejmowanych $\mathrm{w}$ relacjach $\mathrm{z}$ oferentami.

\section{Podsumowanie}

Na podstawie przedstawionych rozważań można stwierdzić, że znaczna część respondentów należała do grupy potencjalnych prosumentów. Wykazywali oni bowiem świadomie otwartą postawę wobec możliwości angażowania się w działania marketingowe. Gotowość do wspólnego tworzenia (wraz z oferentami lub innymi nabywcami) produktów i innych elementów oferty marketingowej miała znaczenie, jeśli chodzi o zakres faktycznej aktywności prosumpcyjnej ankietowanych. Osoby cechujące się otwartą postawą okazały się bardziej aktywne w porównaniu z osobami niewykazującymi chęci uczestniczenia w działaniach marketingowych. Było to zwłaszcza widoczne w przypadku zachowań podejmowanych w ramach prosumpcji internabywczej.

Na postawie wyników testu Kruskala-Wallisa można powiedzieć, że wspomniana cecha była różnicująca w sposób statystycznie istotny aż 14 z 15 analizowanych zachowań prosumpcyjnych. Wyniki przeprowadzonych badań potwierdzają zatem sformułowanie zawarte w hipotezie badawczej w odniesieniu do respondentów. Profile semantyczne opracowane dla grupy ankietowanych wykazujących gotowość do udziału w działaniach marketingowych i dla osób nieprzejawiających otwartej postawy w tym zakresie potwierdzają występowanie wyraźnych różnic w aktywności przedstawicieli każdej z obu grup.

Oferenci powinni zatem podejmować aktywne działania w celu wzbudzania otwartości na współdziałanie prosumpcyjne w przypadku osób niewykazujących obecnie gotowości do angażowania się w działania marketingowe, dążąc jednocześnie do przekształcenia $41 \%$ potencjalnych prosumentów w prosumentów faktycznych, świadomie uczestniczących w różnorodnych formach aktywności marketingowej.

\section{Literatura}

ARVIDSSON A., 2010: The Ethical Economy: New Forms of Value in the Information Society? Organization 17(5), 637-644. 
BAUER R.M., GEGENHUBER T., 2015: Crowdsourcing: Global search and the twisted roles of consumers and producers, Organization 22(5), 661-681.

BRUNS A., 2008: Blogs, Wikipedia, Second Life, and Beyond: From Production to Produsage, Peter Lang, New York.

BRUNS A., 2009: From Prosumer to Produser: Understanding User-Led Content Creation, artykuł zaprezentowany na Transforming Audiences, London, 3-4 września, http://produsage.org/node/67 [dostęp: 04.02.2017].

COVA B., DALLI D., 2009: Working Consumers: The Next Step in Marketing Theory? Marketing Theory, 9(3), 315-339.

COVA B., DALLI D., ZWICK D., 2011: Critical Perspectives on Consumers' Role as 'Producers': Broadening the Debate on Value Co-Creation in Marketing Processes, Marketing Theory 11(3), 231-241.

DOUGHERTY D., 2012: The Maker Movement, Innovations: Technology, Governance, Globalization 7(3), 11-14.

FRAYSSÉ O., O’NEIL M., (red.), 2015: Palgrave Digital Labour and Prosumer Capitalism. The US Matrix, Macmillan, Basingstoke.

FÜLLER J., HUTTER K., FAULLANT R., 2011: Why Co-Creation Experience Matters? Creative Experience and its Impact on the Quantity and Quality of Creative Contributions, R\&D Management, 41(3), 259-273.

HUMPHREYS A., GRAYSON K., 2008: The Intersecting Roles of Consumer and Producer: A Critical Perspective on Co-Production, Co-Creation and Prosumption, Sociology Compass 3(2), 963-980.

KIMMEL A.J., 2015: People and Products: Consumer Behavior and Product Design, Routledge, New York.

MITREgA M., 2015: Streamlining Prosumption of Users of the So-called New Media in the Context of General European Economic Crisis, Handel Wewnętrzny 1(354) 172-181.

MYNARSKI S., 2003: Analiza danych rynkowych i marketingowych z wykorzystaniem programu Statistica, Wydawnictwo Akademii Ekonomicznej w Krakowie, Kraków.

PEJAS-MATYSIK R., SZAFRAŃSKA M., KRASNODĘBSKI A., 2016: Prosumer Attitudes as a New Component of Consumer Behaviour on the Food Market, [w:] International Scientific Days 2016. The Agri-Food Value Chain: Challenges for Natural Resources Management and Society, Slovak University of Agriculture in Nitra, Nitra, 812-819.

PRAHALAD C.K., RAMASWAMY V., 2004: Co-Creation Experiences: The Next Practice in Value Creation, Journal of Interactive Marketing 18(3), 5-14.

RIEDER K., VOß G.G., 2010: The Working Customer - An Emerging New Type of Consumer, Psychology of Everyday Activity 5(2), 2-10.

RITZER G., 2014: Prosumption: Evolution, Revolution, or Eternal Return of the Same? Journal of Consumer Culture 14(1), 3-24.

SZUL E., 2015: Prosumption as the Activity of Modern Consumers - Conditions and Symptoms, Nierówności Społeczne a Wzrost Gospodarczy 31, 347-358.

TOFFLER A., 1980: The Third Wave, Bantam, New York.

TOFFLER A., 1990: Powershift: Knowledge, Wealth, and Violence at the Edge of the 21st Century, Bantam, New York. 


\begin{abstract}
Abstrakt
Artykuł ma charakter teoretyczno-empiryczny. Zostały w nim przedstawione wybrane zagadnienia związane $\mathrm{z}$ działaniami podejmowanymi przez prosumentów jako aktywnych nabywców. Wskazano na rosnące znaczenie prosumentów jako uczestników współczesnego rynku konsumpcyjnego oraz określono ich podstawowe segmenty. Dążono do osiagnięcia trzech celów badawczych: zidentyfikowania gotowości respondentów do angażowania się w działania marketingowe; określenia znaczenia gotowości respondentów do angażowania się w działania marketingowe, jeśli chodzi o zakres ich zachowań prosumpcyjnych; opracowania profili semantycznych respondentów jako potencjalnych lub faktycznych prosumentów. W procesie ich realizacji weryfikacji empirycznej poddano hipotezę badawczą mówiąca, że postawa respondentów wobec aktywności marketingowej determinuje zakres ich zachowań prosumpcyjnych. Dane pierwotne zebrane przez autorkę za pomocą metody badania ankietowego zostały poddane analizie statystycznej. W jej ramach zastosowano test Kruskala-Wallisa. Jego wykorzystanie pozwoliło na stwierdzenie, że gotowość ankietowanych do uczestniczenia w działaniach marketingowych jest cechą różnicującą w sposób statystycznie istotny ich zachowania prosumpcyjne. W przypadku respondentów hipoteza badawcza została tym samym potwierdzona.
\end{abstract}

Słowa kluczowe: prosument, prosumpcja, oferent, marketing

\title{
Prosumer as the active participant of marketing activities
}

\begin{abstract}
The article is of theoretical-empirical nature. Chosen aspects of prosumers' activities were presented. The growing meaning of prosumers as the participants of contemporary consumption market was underlined. Their segments were shown too. The three research aims were: to identify the readiness of respondents to engage in marketing activities; to identify the meaning of respondents' readiness in the relation in the scope of their prosumeric behaviours; to prepare semantic profiles for respondents as the potential or actual prosumers. In the process of the realization of these aims, the following research hypothesis was verified: respondents' attitude towards marketing activity determines the scope
\end{abstract}




\section{6}

of their prosumeric behaviours. The Kruskal-Wallis test was used to primary data gathered by the author. Its applying allowed to state that the respondents' readiness for taking part in marketing activities was factor differentiating their prosumeric behaviours. The research hypothesis was confirmed in the case of respondents.

Key words: prosumer, prosumption, tender, marketing 